\title{
NOSTALGIA AS A DEVICE FOR DEALING WITH TRAUMATIC EXPERIENCES DURING THE COVID-19 CRISIS
}

\author{
Bilyana Todorova \\ https://orcid.org/0000-0001-7854-3425 \\ Scopus Author ID: $\underline{57200216276}$ \\ b_stoianova@hotmail.com \\ South-West University "Neofit Rilski”, Bulgaria
}

Gergana Padareva-Ilieva

https://orcid.org/0000-0002-5734-298X

Scopus Author ID: $\underline{57200215060}$

gery_p2000@yahoo.com

South-West University "Neofit Rilski”, Bulgaria

\section{Received January 13, 2021; Revised March 5, 2021; Accepted May 19, 2021}

\begin{abstract}
The paper is an investigation of nostalgia in its diverse manifestations in social media, mainly Facebook, during COVID-19 crisis in Bulgaria and is based on pre-observation which shows that communication through social media at that period was largely nostalgic. The study considers nostalgia as a strategy for dealing with the 2020 state of emergency during which the lack of physical contact and social experiences can create preconditions for anxiety, depression and fear leading to traumatic consequences. The research is based on empirical material actively collected using the method of the included observation in the period from the $15^{\text {th }}$ of March 2020, when the state of emergency in connection with COVID-19 was declared in Bulgaria, until the $30^{\text {th }}$ of June 2020. The purpose of the paper is to present the nostalgic modes in Facebook and to reveal the reasons for their success as communicative and social messages. Applying interdisciplinary and multimodal approach the study describes the nostalgic manifestations by classifying thematically the initiatives, communication strategies and topics, oriented towards the past, as well as revealing their meaning for the society. The results show that the main role of nostalgic Facebook modes is to unite people in times of isolation, to raise their spirit and thus save them from the traumas that the COVID-19 crisis can cause. The multimodal analysis of the Facebook images from the empirical data confirms that social media and modern technologies make it possible to create 'new products' based on old stories or memories that acquire a new meaning in the specific COVID-19 situation, modelled by the culture and mentality of Bulgarians in isolation.
\end{abstract}

Keywords: nostalgia, COVID-19, Bulgarians, social media, trauma

Тодорова Біляна, Падарєва-Ілєва, Гергана. Ностальгія як засіб подолання травматичого досвіду під час пандемії COVID-19.

Анотація. Стаття має завданням дослідити ностальгю у розмаїтті ії проявів у соціальних мережах, головним чином у Facebook, під час кризи COVID-19 у Болгарії. Дослідження грунтується на попередньому спостереженні, яке показує, що спілкування шляхом соціальних мереж в той період було здебільшого ностальгічним. Автори розглядають ностальгію як стратегію боротьби 3 надзвичайним станом 2020 року, під час якого відсутність фізичного

(C) Todorova, Bilyana; Padareva-Ilieva, Gergana, 2021. This is an Open Access article distributed under the terms and conditions of the Creative Commons Attribution 4.0 International Licence (http://creativecommons.org/licenses/by/4.0).

East European Journal of Psycholinguistics, 8(1), 110-124. https://doi.org/10.29038/eejpl.2021.8.1.tod 
контакту та соціального досвіду могли створити передумови для тривоги, депресії та страху, що призводять до травматичних наслідків. Дослідження використовує емпіричний матеріал, дібраний із використанням методу включеного спостереження в період 315 березня 2020 року, коли в Болгарії було оголошено надзвичайний стан у зв'язку з COVID-19, до 30 червня 2020 року. Мета статті - представити види ностальгічних переживань у Facebook та розкрити причини їхньої популярності/успішності як комунікативних та соціальних повідомлень. Застосовуючи міждисциплінарний та мультимодальний підхід, дослідження описує ностальгічні прояви, класифікуючи тематично ініціативи, комунікаційні стратегії та теми, зорієнтовані на минуле, а також виявляючи їхнє значення для суспільства. Результати засвідчують, що головна роль ностальгічних переживань у Facebook - об'єднувати людей у періоди ізоляції, піднімати їхній дух і тим самим рятувати їх від травм, які може спричинити криза COVID-19. Мультимодальний аналіз зображень Facebook на основі емпіричних даних переконує, що соціальні медіа та сучасні технології дають змогу створювати «нові продукти» на основі старих історій чи спогадів, що набувають нового значення в конкретній ситуації COVID-19, модельованій культурою і ментальністю болгар в ізоляції.

Ключові слова: ностальгія, COVID-19, болгари, сочіальні мережі, травма.

\section{Introduction}

The concept of nostalgia has become very popular in the last decade, and the observations show that its influence at the time of crises increases. Although nostalgia is broadly used as a manipulative means by PR specialists, politicians, etc. (Padareva-Ilieva \& Todorova, 2016), it has also been used as a means of overcoming the psychological consequences of the isolation, anxiety and trauma during the COVID-19 crisis since the beginning of March 2020 because of its potential to bond with others (Niemeyer \& Wentz, 2014, p. 129), to increase optimism and to mobilise people for action (FioRito \& Routledge, 2020).

\section{The concept of nostalgia}

As is known, "[t]he word "nostalgia" comes from two Greek roots: vó $\sigma \tau \varsigma$, nóstos ("return home") and ờ $\lambda$ os, álgos ("longing")[...] In spite of its Greek roots, the word "nostalgia" did not originate in ancient Greece [...]The word was coined by the ambitious Swiss student Johannes Hofer in his medical dissertation in 1688." (Boym, 2001)

It could be seen as a negative phenomenon (for example, Abramov, Chestiakova, 2012), as it "fuelled populism and nationalist identity politics" (Menke \& Schwarzenegger, 2016, p. 2).

At the same time nostalgia may be seen "as a creative and progressive resource, a tool for commodification, or an agent for identity and community building to articulate cultural or generational belonging" (Menke \& Schwarzenegger, 2016, p. 2). The positive consequences of nostalgia have been also investigated (Sedikides, 2015; Sedikides \& Wildschut, 2016, etc.). Kalinina (2016, p. 11) makes an overview of the research of different investigators, who consider that nostalgia is a way for easier crossing through difficult times and concludes that 
"[n]ostalgia, therefore, can be regarded as an essential tool that individuals use to adapt to unavoidable changes in life." Moreover, nostalgia may help people to connect with others (Batcho, 2007) and it may provoke inspiration, influence positively creativity and increase optimism (Sedikides \& Wildschut, 2016). As we are all living in unprecedented times - the world lockdown with an obscure end has never happened before, all these features become important.

Nostalgia may be seen as an emotion as well. Havlena and Holak mention that the "bittersweet" quality of the emotion is a distinguishing characteristic of nostalgia. It refers back to an earlier period in the individual's life and draws on biased or selective recall of past experiences. According to authors, it may be described as "a painful yearning to return home" and it is broadly used in advertising, marketing and PR. As we may see, at the time of corona-crisis when the home was the permanent place of living, nostalgia changes its parametres and starts representing the longing for the previous life, the longing for normality. And this is not surprising. The person who is sent away desires to come home, the person at their home dreams about travelling. At the time of lockdown, the virtual memories which trigger nostalgic feelings became a path for the escape from the real immobility, from the spatial closure and by the help of nostalgia they re-construct the present, evoking memories to life.

As social life of people is very important for their mental and even physical health, the so-called social isolation (some people protested against the term and insisted on the terms physical distance and social solidarity) challenged everyone and nostalgia seems to be one of the strategies for overcoming the situation. According to FioRito \& Routledge (2020) "[n]ostalgia involves reflecting on past experiences but it motivates affective states, behaviors, and goals that improve people's future lives". Sweeny (2020) states that "nostalgia is an emotional response to change". The author describes the two routes to nostalgia. "The first route to nostalgia we can identify is through a conscious longing for a different time or place. The route is connected to some memory or quasi memory that one has and it can be purposefully triggered, perhaps by being asked to consider some element of dissatisfaction with the present or simply the awareness of a substantial change in circumstances" (Sweeny, 2020). The other one "is through sensory data and it comes over one in a way that is immediate". (Ibid)

In the present situation, we could see both routes have been activated - the lockdown makes people dissatisfied with staying home and fearing; social media allows them to remember the past via some leisure activities: games, shares and others techniques which became very popular in the spring of 2020. Nostalgia gives people "the freedom to look back and find comfort in pre-pandemic times" (Gammon \& Ramshaw, 2020, p. 1), as "[a] mixture of leisure and nostalgia during difficult times, for some, perhaps offers a palliative respite through social interaction, distraction, and escape as become a welcomed distraction across the generational spectrum." (Ibid, p. 4) 


\section{Research methodology}

The aim of the study is to present nostalgia as a strategy for dealing with the state of emergency during COVID-19. In previous publications (Padareva-Ilieva \& Todorova, 2016; Todorova \& Padareva-Ilieva, 2018) nostalgia has been considered as a successful manipulative strategy applied in the Bulgarian media environment. During the state of emergency in 2020 nostalgic winds, memories of the past and literary reminiscences proved to be a successful strategy for dealing with physical isolation.

So, simultaneously with the calls Stay home, it could save lives, other calls appeared on social media - To be healthy with poetry, We will cope together, as well as campaigns such as The Challenge Accepted, Memories in time of quarantine - all of them we consider as opportunities for dealing with the situation, having in mind that the state of emergency and physical isolation put the people in Bulgaria in front of a challenge that they had not faced so far. Man is a social being, and the lack of physical contact and social experiences can create preconditions for anxiety, depression, fear and this could lead to traumatic consequences. (Brooks et al., 2020, Ron, Cuéllar-Flores, 2020, Pandey et al., 2020, Odriozola-González et al., 2020, etc.). To save themselves and to preserve the spirit, to compensate for the lack of real human contact and normalcy in everyday life, people turned to memories. Communication through social media in the months of isolation was largely nostalgic.

The purpose of this paper is to 1) present the nostalgic modes in Facebook and classify thematically the initiatives, communication strategies and topics in the public space, oriented towards the past; 2) reveal the reasons for their success as communicative and social messages through their meaning in social media during an emergency situation.

\section{Tools}

In order to achieve the above goals, a set of methods and approaches was used in the analysis and classification, as well as in the explanation of the reasons for the nostalgic convertibility in the public space, especially intensified during COVID-19. Such a complicated phenomenon insists on using an interdisciplinary approach as so ethnolinguistic, linguocultural, linguopragmatic, psycholinguistic aspects of the investigated topic should be kept in mind. Moreover, the apparatuses of the discourse analysis, the descriptive method, and the content analysis also are appropriate (Todorova \& Padareva-Ilieva, 2018). To investigate the cultural shaping of the nostalgic posts, to explain their social use in an emergency situation and to conceptualize the research data the multimodal analyses theories are also applied. A large scale of multimodal approaches have been applied so far and their value has been proved in different social, linguistic and other types of social media research as analysing and interpreting big social media data (Ch'ng et al., 2019), for example, looking into the Instagram's metonymy (Koowuttayakorn, 2018) on the basis of 
multimodal semiotic approach (see Kress, 2009; Jewitt, Henriksen, 2016), doing content analysis of commercials (Serafini, Reid, 2019), investigating the role of images in social media analytics using multimodal digital humanities approach (O'Halloran et al., 2014), examining the multimodal dialogue on social media (Jovanovic \& Van Leeuwen, 2018), or exploring internet memes as "Tactical" social action applying a multimodal critical discourse analysis approach (Ben Moussa et al., 2020), etc. The aims set in our study also require the use of inter-disciplinary and multimodal approach so as to explore the interdependence between the design and the use of nostalgic posts in social media, their role and meaning for the individual himself and for the community in the life-threatening situation in Bulgaria in 2020. The research is based on empirical material, which is carefully excerpted, analysed, systematised and classified aiming to not just describe and present the collected material, but to find the causal links between the event that gave rise to the specific communication, and nostalgia as a strategy for overcoming, experiencing the same event.

\section{Procedure}

As the communication at the time of physical isolation becomes mostly virtual, the empirical material from social media have been excerpted for the study. It includes posts (topics, personal opinions, initiatives) from Facebook personal profiles and groups. The material was actively collected using the method of the included observation in the period from 15.03.2020, when the state of emergency in connection with COVID-19 was declared in Bulgaria, until 13.05.2020, when it was terminated. During the following "emergency epidemiological situation" when the measures were weakened slowly almost the same trends were still observed. So we decided to add some material from 13.05.2020 to 13.06.2020.

The collected empirical data containing a nostalgic nuance has been classified and systematised into several thematic groups, concerning historical memories; personal childhood memories, literary reminiscences, nostalgic games. All of them will be presented consequently in the next part of the research.

\section{Results and Discussion}

The empirical material from each group was described and analysed according to the above-mentioned methods and approaches.

\section{Historical memories}

Kalinina (2016, p. 11), quoting their previous research (Kalinina \& Menke, 2016) states that "[1]onging for an irrevocably lost moment of personal significance, people become curious and start to enquire about historical events". Are there other periods in time similar to the present, how do people survive, and even could such 
time be a stimulus for achieving something important, creating or inventing? People`s curiosity has found examples which became very popular using the power of social media no matter whether they correspond to the historical truth or not Newton described gravity in 1665 when Cambridge was closed due to a bubonic plague pandemic (Picture 3); the Russian poet Pushkin isolated in Boldino in 1830 (Pushkin's Boldino Autumn, known as the most fruitful in his life) due to an epidemic of cholera, created great works. This is the topic of the next post, and the comment below the picture of the Russian poet "quarantine also has a nice side, sometimes" (Picture 1) shows that the strategy has achieved its goal.

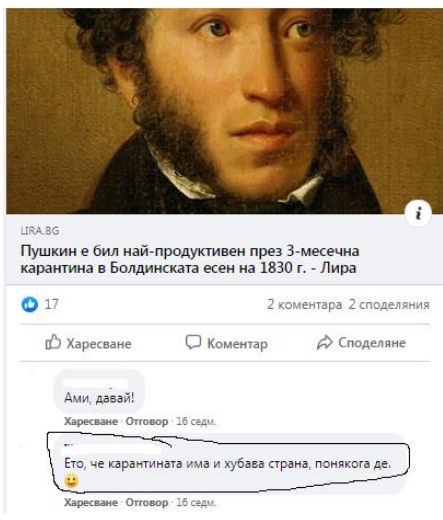

Picture 1.

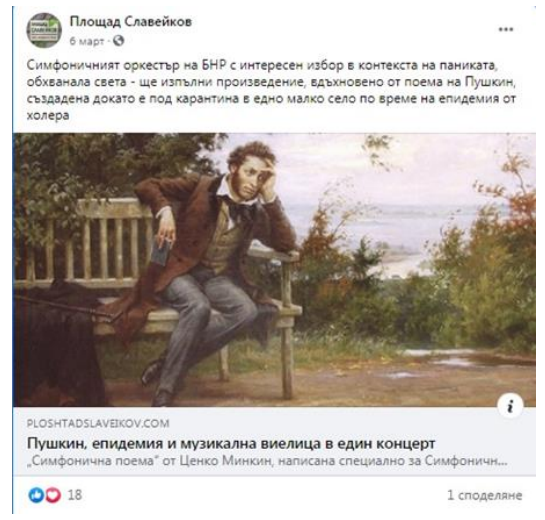

Picture 2.

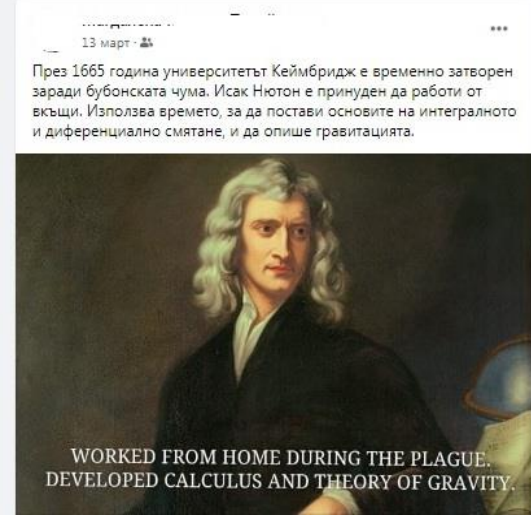

Picture 3.

The same fact about Pushkin`s Boldino period (Picture 1), is used for various purposes in the Internet. The post above Picture 2 says: "The Bulgarian National Radio Symphony Orchestra, with an interesting choice in the context of the panic that has gripped the world, will perform a work inspired by Pushkin, created while quarantined in a small village during a cholera epidemic".

It is an example for an interesting way to promote a new performance during pandemic situation using the photo of Pushkin and an appropriate text as a strategy for recalling an already popular fact. However, this choice is very indicative of what and how we choose to present, respectively to listen, watch and read, during isolation. We could say that the strategy of remembering the past also has the power to govern our present.

In this sense, the search for similar historical memories but from local history reminds about the plague of the late 18th and early 19th centuries in Bulgaria. A Facebook group "Are you from Bansko?" reminiscents about the plague in the town of Bansko titled "The lessons of the history" and explains how remembering past is a strategy for survival in the present time: "If we break away from the current troubles... if we look back at the past, we will notice the light that shines ..., we will find grounds for optimism and support for our faith in good... There are many hardships that humanity has gone through in its development... The epidemics have been an integral part of life for centuries. However, Bulgarians do not disappear, but survive." 
The text is accompanied by a black and white picture of citizens from the past evidence for the authenticity of the story (See Picture 4).

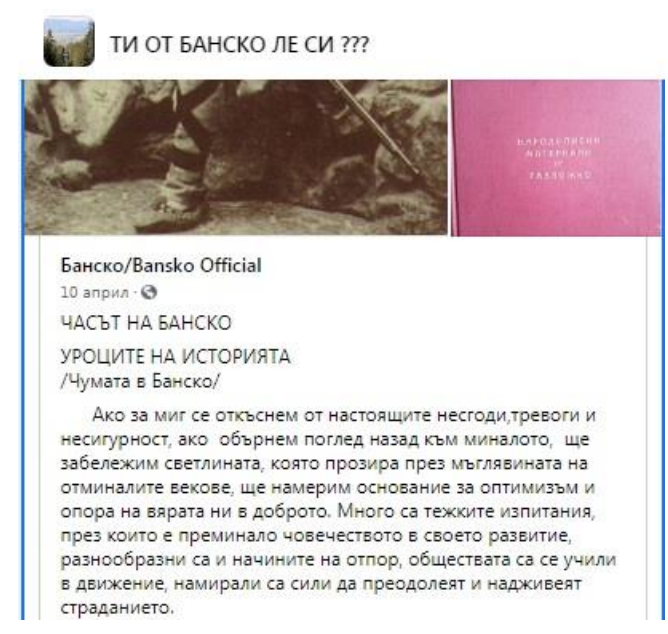

Picture 4.

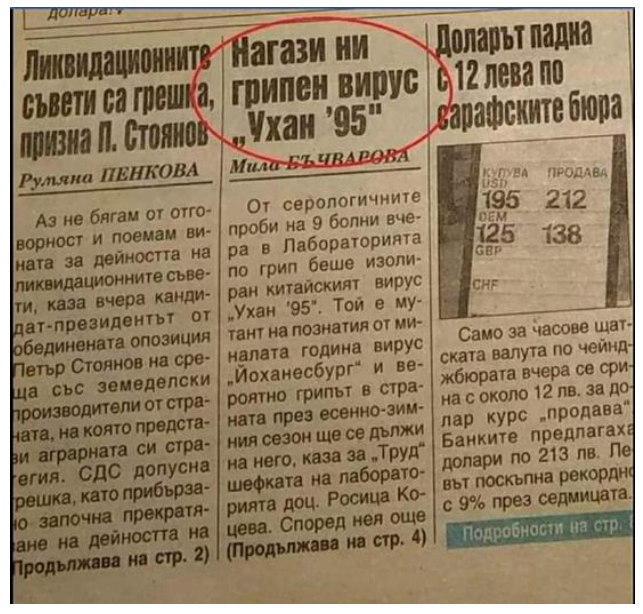

Picture 5.

Old newspaper copies (Picture 5) with news for the coronavirus Uhan from the year 1995 appeared also as posts in Facebook accompanied by comments or not (Picture 5) with the underlined title "Uhan'95 flu virus steps on us" so as to draw the users'attention to the news content which appears as a deja-vu in the current situation. The available comments below saying "The corona is new, ha?!?" or "The same old new virus" and the newspaper news itself aim to calm people down and reduce their fear of encountering something new and unfamiliar.

All the posts as the abovementioned compositions of an image, text and title, saved their popularity in Facebook for a long time in these first two months of the pandemic. Why do many users choose to re-publish these posts as a product to communicate with? We can assert with confidence that the reason is hiding in the social meaning they contain. We consider them as semiotic resources - meaningful materials that people use for communicative purposes (Jewitt \& Henriksen, 2016), a recall from the past that is actualised in a concrete social context (Van Leeuwen, 2005 , p. 285). Once these facts were just historical, scientific or media facts. Now they live 'a totally new life' as 'Facebook products' which have their role for the preservation of the individual and the community in times of fear, isolation, depression.

\section{Personal memories}

The memory of the personal past is also a manifestation of nostalgia in the time of COVID-19 crisis. Personal childhood memories 'arise' in Facebook with old black and white photos from tape cameras, photos from kindergarten, high school graduation or just memories without masks. Sharing pictures from the past, some of which provoked a lot of personal memories in the comments below, was a Facebook initiative that brought a strong emotional response. As Kalinina said "[o]pening 
shoeboxes that contain various reminders of our individual pasts $[\ldots]$ can unleash a flood of cherished memories that together constitute our personal and cultural identities." (Kalinina, 2016, p.6).

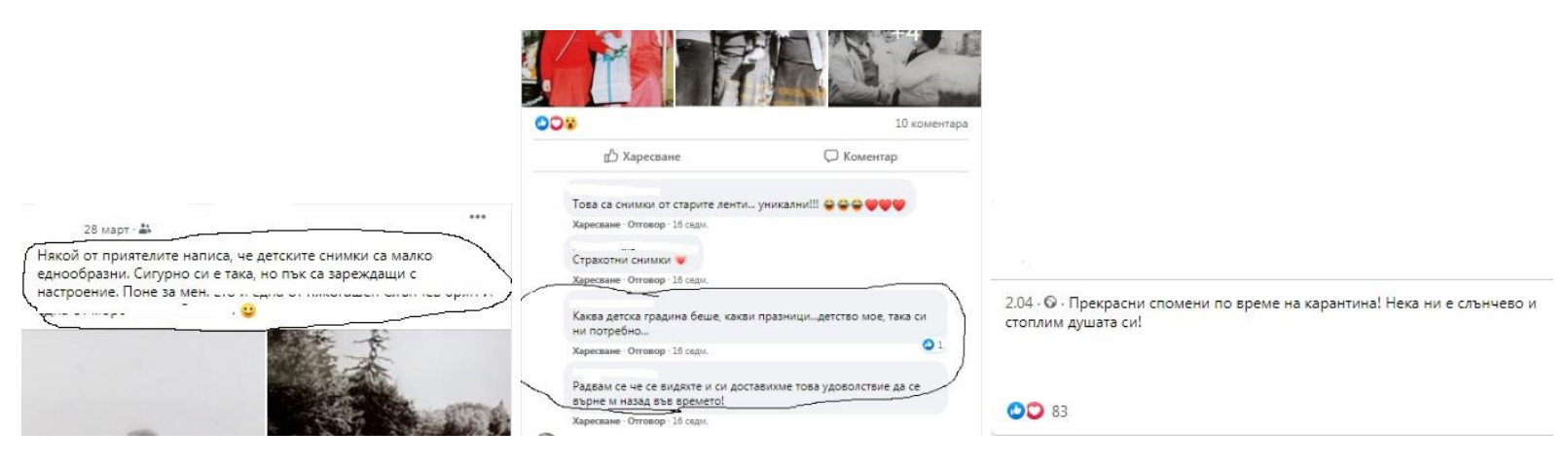

Picture 6.

Picture 7.

Picture 8.

The posts above or below photos are eloquent about about how important the personal memories are for the users: "One of the friends wrote that the children's photos are a bit monotonous. Sure, but they're invigorating", says the text in Picture 6 publishing two black-and-white photos from childhood. "Wonderful memories during the quarantine. Let it be sunny and warm in our souls" (Picture 8). Sometimes the published photos from kindergarten or high school graduation cause a real furore of emotional posts from other users who have identified themselves in these photos (Picture 7). "These are photos from the old tapes. Unique!", "Great pictures", "What a kindergarten it was!...", "I'm glad you saw each other and that we took the pleasure to go back in time" (Picture 7). This is how personal memories are in fact shared memories, memories of people who have once shared a moment in their lives and this moment now through social media unites them again and saves them from isolation. Something more, these black-and-white photos are actually part of the cultural identity of an entire generation that has grown during or shortly after socialism. A generation that suffered consciously because of COVID-19 isolation and found salvation in communicating memories via Facebook. So instead of experiencing traumatic and negative emotions due to physical isolation (Saladino, Algeri, \& Auriemma, 2020) people indulge in warm memories that direct their attention away from COVID-19 reality.

\section{Literary reminiscences}

The situation provokes people to share parts of books devoted to other epidemics (usually plague epidemic). Although these novels and stories recall past but difficult times, they as well give some aesthetic pleasure, provoke solidarity, reflective thoughts, and help to make parallels with the present situation. At the same time, the literary texts make the described historical events more vital and moving. Sometimes the panic now provokes interest to similar events in the past (Picture 9). The text under picture 9 states: "70 years later: Albert Camus' The 
Plague - a bestseller because of the coronavirus", and the text over the picture of Camus and the book covers says: "The panic empties movies theatres, fiction for deadly diseases and epidemics is sought".

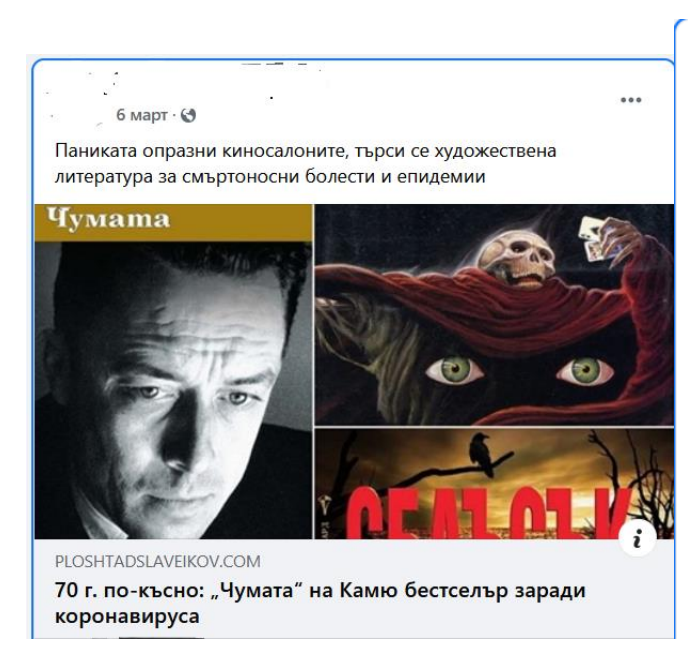

Picture 9.
29 март $\cdot \dot{0}$

„Напастта не е по мярката на човека, затова си казваме, че напастта е нереална, това е лош сън, който ще отмине. Но тя невинаги минава и, от лош сън в лош сън, хората заминават, и хуманистите на първо място, защото не са взели своите предпазни мерки."

-- Албер Камю, Чумата

"Le fléau n'est pas à la mesure de l'homme, on se dit donc que le fléau est irréel, c'est un mauvais rêve qui va passer. Mais il ne passe pas toujours et, de mauvais rêve en mauvais rêve, ce sont les hommes qui passent, et les humanistes en premier lieu, parce qu'ils n'ont pas pris leurs précautions".

-- Albert Camus, La Peste

ВЗЕМЕТЕ ВСИЧКИ ВЪЗМОЖНИ ПРЕДПАЗНИ МЕРКИ!!! БЪДЕТЕ РАЗУМНИ!!!

Picture 10.

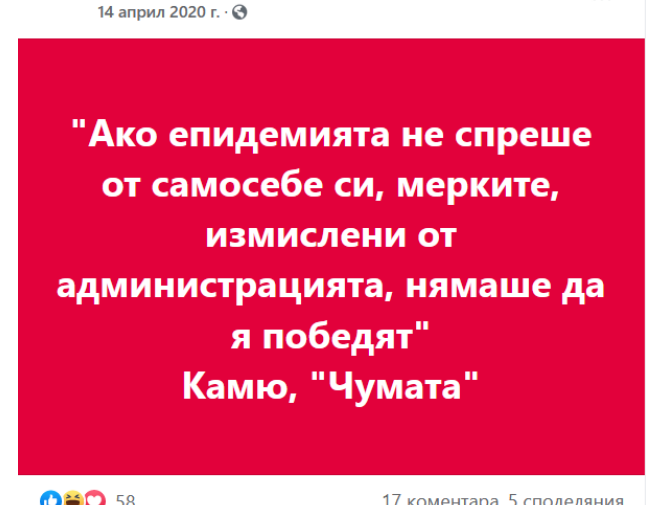

Picture 11.
19 март 2020 г. · 9

ПРИЗРАК БРОДИ ...

Отново броди призрак из целия свят - призракът на

коронавируса. "Тя започна ... в източните области и след като ги лиши от безброй люде, се местеше неспирно от едно място на друго и се разпростря чак на запад, сеейки след себе си смърт и печал. Против нея бяха безсилни и мъдростта, и предвидливостта човешка." Описание на чумата във Флоренция през 1348 г. в "Декамерон" на Бокачо. Някои печелят от пира по време на чума, други губят човешкия си облик, индивидът се изправя пред морален избор и пада цената на човешкия живот.

Picture12.

In picture 10 a part of Camus' novel is cited in Bulgarian and French: "A pestilence does not have human dimensions, so people tell themselves that it is unreal, that it is a bad dream which will end. But it does not always end and, from one bad dream to the next, it is people who end, humanists first of all because they have not prepared themselves." The text gives the reason for the author of the post to exclaim: "Take all possible precautions! Be reasonable!"

Picture 11 presents a post with the following citation from Camus' novel: "If the epidemic hadn't stopped by itself, measures, devised by the administration, would not have overcome it."

In Picture 12, the description of the plague in Florencia in 1348 in Boccaccio's "The Decameron" is presented. "...several years earlier had originated in the Orient, where it destroyed countless lives, scarcely resting in one place before it moved to 
the next, and turning westward its strength grew monstrously. No human wisdom or foresight had any value:"1 The post discusses some moral problems connected to such crises: "Some gain from the feast in time of plague ${ }^{2}$, others lose their human face, the individual faces a moral dilemma and the cost of human life falls". As is seen, the literature evokes thoughts, emotions and gives hope as all these severe crises are behind us.

Bulgarian stories about epidemics from some of the most famous writers are also mentioned:

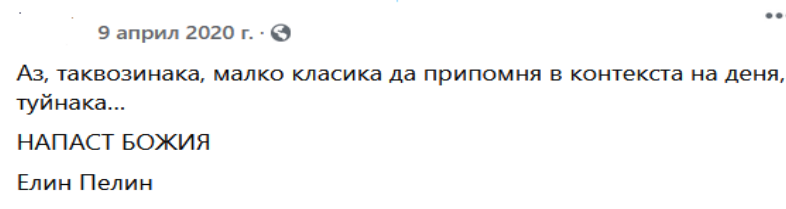

Picture 13.

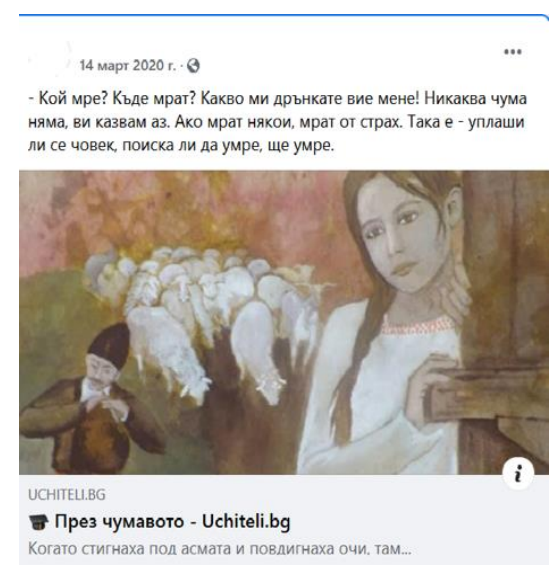

Picture 14 .

Picture 13 introduces Elin Pelin's story "The Plague of God", written in 1901. The plot of the story contradicts scientific knowledge to traditional beliefs. The author of the post reminds us of the story starting with the words: "I'm recalling a bit of a classic in the context of the day..." The critical situations years and even centuries ago through the eyes of the writers are seen as lessons of the past which may teach us and give us hope as science has been much developed since then.

Picture 14 presents Yordan Yovkov's story "Through the plague" (1927) with the next part quoted: "Who dies? Where do they die? What do you tell me? There is no plague, I'm telling you. If some people die, they die because of fear. If the person is afraid, if they want to die, they will die." The picture presents the idyllic rural picture with sheep, a shepherd and a beautiful girl in close-up. As the main message of the whole Yovkov's text is that love may overcome fear and even the sacrifice of love is beautiful and blessed, the idea of the post is to give some hope.

To sum up, this group is mostly text-focused - images are few and only picture 14 functions as a multimodal item. The quoted literary texts are not always really positive ones. However, all of them present some similar epidemics in the past. The fact that these crises have been overcome gives some hope and provokes thoughts and memories. At the same time, it develops bonds with people, who like, share or

\footnotetext{
${ }^{1}$ The English translation used here is made by Richard Hooker (1993) https://sourcebooks.fordham.edu/source/decameronintro.asp

${ }^{2}$ Feast in Time of Plague is a title of a play by Aleksandr Pushkin
} 
comment on the posts. We may conclude that these books, like television, function as "a complex time machine navigating in between an ephemeral present, an often unknown future and an intriguing past”. (Niemeyer \& Wentz, 2014, p. 130).

\section{Nostalgic games}

One of the most popular nostalgic games during quarantine was 'travelling with memories, i.e. photos with comments such as "Good memories feed the soul during isolation". Travel with memories during quarantine is a very productive initiative which provoked emotional response and at the same time was fun for the users. They publish their photo memories of experiences, travels, etc. before isolation. Travel constraints during COVID-19 pandemic affected tourist nostalgia (Jian, Lin, \& Zhou, 2021) and for the people who are fond of travelling this was the only way to overcome those constraints.

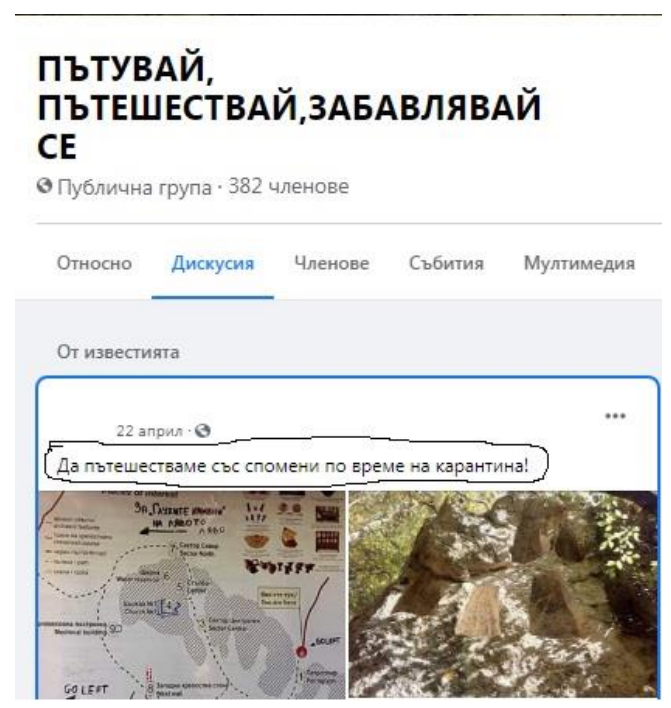

Pictire 15.

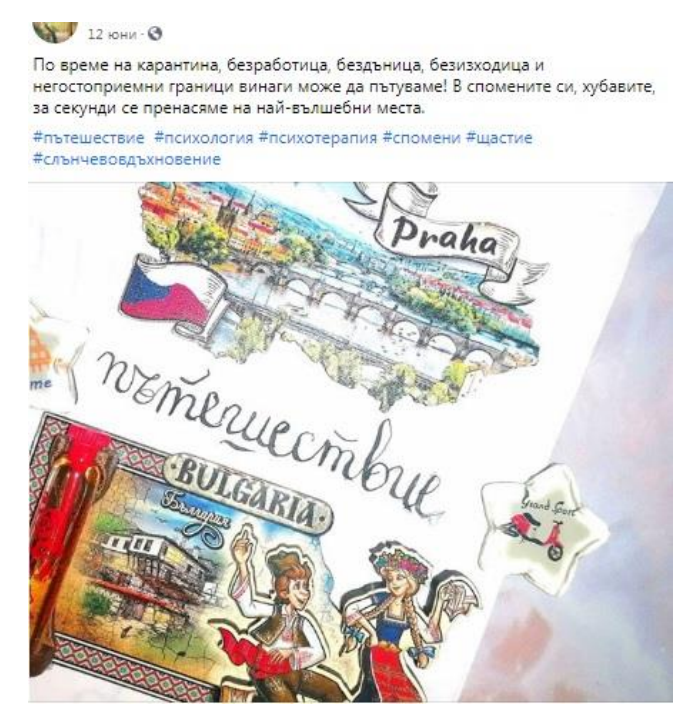

Picture 16.

There were public Facebook groups as "Travel and have fun" which invite there group members to "travel' with memories during quarantine (Picture 15). A map with places to visit is an appropriate picture to accompany such an invitation. And the responses with travel memories literally flooded Facebook. Pictire 17, for example, presents a post saying "Apparently this spring we'll spend in memories" above a picture from a family journey abroad 7 years ago. Other inviting posts are much more impressive both in terms of text and in terms of the image (Picture 16). The text says: "During quarantine, unemployment, hopelessness and inhospitable borders we can still travel. In our good memories, we are transported to the most magical places in seconds" and the image contains a detail reminding of fridge magnets bought during travelling, from a landscape of Prague and from an old Bulgarian house with people dancing in folk costumes. 
There were also websites in Facebook as the Bulgarian Motorcycle Media which published on 2nd April, 2020 the following post: "At this time of the year we have always opened another motorcycle season. Well, this year's openings did not happen, so today's tease for friends and readers is to put a photo with the opening of the motorcycle season from previous years. [...]we may be in quarantine, but we have memories, right?" (Picture 18).

Returning, although virtually, to better times, to good memories and pleasant emotions is the meaning of the nostalgic games. On the other hand, they unite Facebook users to overcome physical distance and difficult times during COVID19.

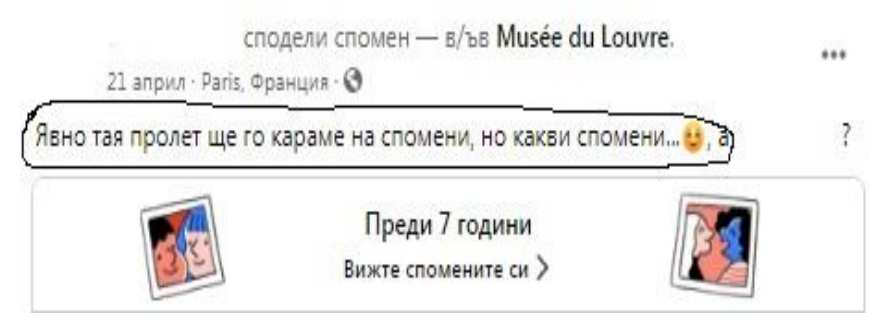

Picture 17.

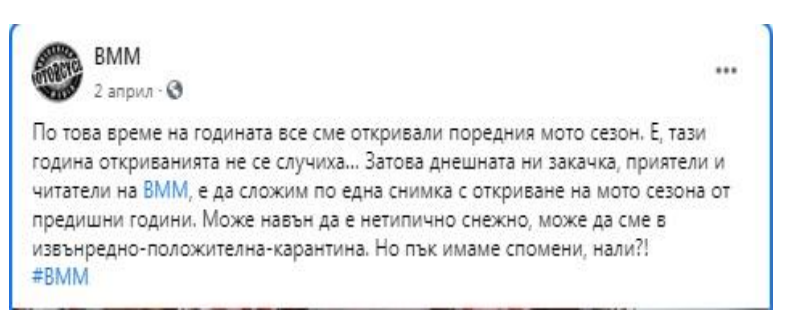

Picture 18

As is seen, several groups of Facebook posts, which provoke nostalgia at the time of the state of emergency in Bulgaria (March-June 2020) have been found. They serve as a "glue" between the past and the present calling forth different times and places. The Bakhtin's chronotope is a complicated phenomenon and space and time are interrelated not only in the "real world" but in the "virtual" life as well. Kalinina (2016, p. 8) says that "[ $\mathrm{t}]$ hrough creative practices such as interior design, packaging and branding, collecting souvenirs, and collective remembering in online communities engaged in the sharing of various media of the past, nostalgia constructs the past and reshapes the physical and virtual world we inhabit in our everyday lives. Hence, temporal nostalgia has never been separate from spatial nostalgia; rather, they have always been interconnected and entangled". The connection between time, space, personal and social history and nostalgia is expressed by Bartlett (2020), who adds: "Places are saturated with meanings, made across many different modes: visual, spatial and musical as well as oral and memorial. But a cultural system is more than nostalgia and it is as material as it is semiotic." (Bartlett, 2020, p. 17). That is why the posts are multimodal, they present personal or historical information which is both visual (pictures, sometimes videos, etc.) and textual (memories, quotes from books or the whole stories). All of them bond people, try to calm, to inspire, to ponder deeply. More investigations of other media - traditional or web-based, may show some similar or different observations concerning the role of nostalgia in coping with the traumatic situation linked with the COVID-19 crisis. 


\section{Conclusions}

The study which investigates the publications with a nostalgic nuance in social media between March and June 2020 have shown the following groups of multimodal posts:

- Presenting historical memories - memories of great personalities who in past centuries, in time of isolation due to pandemics, made great discoveries, created literary texts (Newton, Pushkin); memories of similar periods in Bulgaria in past centuries (the plague in the late 18th and early 19th century);

- Presenting personal childhood memories - publishing old black-and-white photos from tape cameras, photos from kindergarten, high school graduation;

- Presenting literary reminiscences - the quotations from literary works are shared to remind us of past epidemics, to calm us that the situation is not unprecedented and to make us wiser and more patient.

- Presenting nostalgic games - users or Facebook groups initiatives as "Travel with memories during quarantine" which challenge the others to publish their photos of experiences, travels, etc. before isolation. Our observations show that this group because of the multiple responses of the nostalgic initiatives is the largest one and it needs more profound investigation.

As a result of this study, we could say that nostalgia through its diverse manifestation in social media manages to unite people in the presence of physical isolation, to take care of their mood, to remind them of long-forgotten wonderful experiences and thus save them from trauma which the COVID-19 constrictions and fears may cause. Social media and modern technologies make it possible to create 'new products' based on old, forgotten stories or memories that live 'a new meaningful life' in the specific COVID-19 situation, modelled by the culture and mentality of Bulgarians in isolation.

\section{References}

Abramov, R., Chestiakova, A. (2012). Nostalgic images of the Soviet's recent past: The media activism of Leonid Parfenov. International Journal of Cultural Research, 1(6), 52-58.

Batcho, K. I. (2007). Nostalgia and the emotional tone and content of song lyrics. American Journal of Psychology, 120, 361-381.

Bartlett, T. (2020). Time, the deer, is in the wood: Chronotopic identities, trajectories of texts and community self-management. Applied Linguistics Review. https://doi.org/10.1515/applirev$\underline{2019-0134}$

Ben Moussa, M., Benmessaoud, S., Douai, A. (2020) Internet memes as "tactical" social action: A multimodal critical discourse analysis approach. International Journal of Communication, 14, 5920-5940. 
Boym, Sv. (2001) Adoptation and elaboration from Svetlana Boym, The Future of Nostalgia, Basic Books, NY 2001. Retrieved from: http://monumenttotransformation.org/atlas-oftransformation/html/n/nostalgia/nostalgia-svetlana-boym.html

Brooks, S.K., Webster, R.K., Smith, L.E., Woodland, L., Wessely, S., Greenberg, N., Rubin, G. J. (2020). The psychological impact of quarantine and how to reduce it: rapid review of the evidence. Lancet, 395, 912-920. https://doi.org/10.1016/s0140-6736(20)30460-8

Ch'ng, E., Li, M., Chen, Z., Lang, J., See, S. (2019) Multimodal approaches in analysing and interpreting big social media data. In Multimodal Analytics for Next-Generation Big Data Technologies and Applications (pp. 361-390). Kah Phooi Seng, Li-minn Ang, Alan Wee-Chung Liew, Junbin Gao (Eds.). Springer. https://doi.org/10.1007/978-3-319-97598-6_15

FioRito, TA, Routledge C. (2020) Is nostalgia a past or future-oriented experience? affective, behavioral, social cognitive, and neuroscientific evidence. Frontiers in Psychology, 11, 1133. https://doi.org/10.3389/fpsyg.2020.01133

Gammon, S., Ramshaw, Gr. (2020) Distancing from the present: Nostalgia and leisure in lockdown. Leisure Sciences. https://doi.org/10.1080/01490400.2020.177399

Havlena, W., Holak, S. (1991) "The Good Old Days": Observations on nostalgia and its role in consumer behavior. In R. Holman, M. Solomon, (eds.), NA - Advances in Consumer Research, 18, (pp.323-329), Provo, UT: Association for Consumer Research.

Jewitt, C., Henriksen, B. (2016) Social semiotics multimodality. In N.-M. Klug, H. Stöckl, (Eds.). Handbuch Sprache im multimodalen Kontext (pp.145-164). Berlin: Walter de Gruyter.

Jian, Y., Lin, J, Zhou, Zh. (2021) The role of travel constraints in shaping nostalgia, destination attachment and revisit intentions and the moderating effect of prevention regulatory focus. Journal of Destination Marketing and Management, 19. https://doi.org/10.1016/j.jdmm.2020.100516

Jovanovic, D., Van Leeuwen, T. (2018) Multimodal dialogue on social media. Social Semiotics, 28(5), 683-699. https://doi.org/10.1080/10350330.2018.1504732

Kalinina, E. (2016) What do we talk about when we talk about media and nostalgia. Medien \& Zeit, 4, 6-15.

Kalinina, E., Menke, M. (2016). Negotiating the past in hyperconnected memory cultures. PostSoviet nostalgia and national identity in Russian online communities. International Journal of Media \& Cultural Politics, 12(1), 59-74.

Koowuttayakorn, S. (2018) An investigation of Instagram's metonymy: A multimodal social semiotic approach. LEARN Journal: Language Education and Acquisition Research Network Journal, 11(1). Retrieved from: https://files.eric.ed.gov/fulltext/EJ1225833.pdf 26122020

Kress, G. (2009) Multimodality: a social semiotic approach to contemporary communication, London: Routledge.

Menke, M., Schwarzenegger, C. (2016) Media, communication and nostalgia. Finding a better tomorrow in the yesterday? Editorial. Medien \& Zeit, 4, 2-5.

Niemeyer, K., Wentz, D. (2014) Nostalgia is not what it used to be: serial nostalgia and nostalgic television series. In K. Niemeyer, (ed). Media and Nostalgia: Yearning for the Past, the Present and the Future (pp. 129-138). London: Palgrave McMillan.

Odriozola-González, P., Planchuelo-Gómez, Ál., Irurtia M.J., de Luis-García, R. (2020)

Psychological effects of the COVID-19 outbreak and lockdown among students and workers of a Spanish university, Psychiatry Research, 290, 113108,

https://doi.org/10.1016/j.psychres.2020.113108

O'Halloran, K.L., Chua, A., Rodlasov, A. (2014) The role of images in social media analytics: a multimodal digital humanities approach. In: Visual Communication (pp. 565-588), D. Machin (Ed.). Berlin: De Gruyter Mouton. https://doi.org/10.1515/9783110255492.565

Padareva-Ilieva, G., Todorova, B. (2016) Nostalgiyata kato sredstvo za manipulatsia v mediate.

[Nostalgia As a Manipulative Strategy in Media]. Ezikov Svyat, 14(2), 41-44. 
Pandey, D., Bansal, S., Goyal, S., Garg, A., Sethi, N., Pothiyill, DI. (2020) Psychological impact of mass quarantine on population during pandemics - The COVID-19 Lock-Down (COLD) study. PLoS ONE 15(10): e0240501. https://doi.org/10.1371/journal.pone.0240501

Ron, A. G., Cuéllar-Flores, I. (2020) Psychological impact of lockdown (confinement) on young children and how to mitigate its effects: Rapid review of the evidence. Anales de Pediatria, 93(1), 57-58. https://doi.org/10.1016/j.anpede.2020.04.008

Saladino, V., Algeri, D., Auriemma, V. (2020) The psychological and social impact of COVID-19: new perspectives of well-being. Frontiers in Psychology, 11, 2550. https://doi.org/10.3389/fpsyg.2020.577684

Sedikides, C., Wildschut, T. (2016) Past forward. Nostalgia as a motivational force. Trends in Cognitive Sciences, 20(5), 319-321. https://psycnet.apa.org/doi/10.1016/j.tics.2016.01.008

Sedikides, C., Wildschut, T., Routledge, C., Arndt, J., Hepper, E. G., Zhou, X. (2015). Chapter FiveTo nostalgize: mixing memory with affect and desire, In J. Olson, M. Zanna, (Eds.), Advances in Experimental Social Psychology (pp. 189-273). Academic Press, 51. https://doi.org/10.1016/bs.aesp.2014.10.001

Serafini, F., Reid, S. (2019) Multimodal content analysis: expanding analytical approaches to content analysis. Visual Communication. https://doi.org/10.1177/1470357219864133

Sweeney, P. (2020) Nostalgia reconsidered, Ratio, 33(3), 184-190. https://doi.org/10.1111/rati.12272

Todorova, B., Padareva-Ilieva, G. (2018). (Ne)zabravenite svetove v novia svyat (Lingvokulturologichen analiz na mediynite poslania). [(Un) forgettable worlds in the new world (Cultural linguistic analysis of the media messages)]. Balkanistic Forum, 1, 212-221.

Van Leeuwen, T. (2005) Introducing social semiotics. London and New York: Routledge. 